\title{
Implementation of E-Government in Health Service Innovation Based on Sikeroki Program in Bontomarannu Health Center of Gowa Regency
}

\author{
Nur Muliasari MS ${ }^{1}$, Ilham Nur Pratama Rahman ${ }^{1}$, Hamrun $^{1}$, Ahmad Taufik $^{1}$ \\ \{muliasarimsnur@gmail.com\} \\ ${ }^{1}$ Universitas Muhammadiyah Makassar, Indonesia
}

\begin{abstract}
In this fourth century industrial Revolution, the government service system given to the public was time to integrate the digital or electronic world in the form of public service. This research is discussed about how the application of electronic government in the innovation of health services based on the program Sikeroki in Bontomarannu district medical center. This research uses qualitative descriptive methodology. The results of this research can be concluded that (1) the application of electronic government in the Innovation based health services Sikeroki program at Bontomarannu district medical center. Includes 3 types of electronic Government, namely (a) Publish, in the terms of publicizing Sikeroki program through website (b) Interact in the terms of interacting Sikeroki this program involving Chating robot, (c) Transact, for the service Transact in Sikeroki program does not exist. (2) Problem of implementation of electronic Government in health service innovations based on Sikeroki program at Bontomarannu District medical center of Gowa There are several obstacles, namely, Internet network that is not smooth, limited use of communication technology by the community, and society is not familiar with the service system based online.
\end{abstract}

Keywords: electronic government, health services, sikeroki

\section{Introduction}

Electronic government is a form of information and communication technology based on the internet, in the influence of the development of globalization in the modern era [1]. Currently electronic government is one of the applications in various developed and developing countries [2]. This clearly looks the government is getting more precise in giving a new idea in the form of innovation. So in applying electronic government in public services, the Government is able to make a rule or policy. Electronic government is the use of internet technology to deliver information and public services to citizens, business partners, suppliers of Government agencies, and people working in the public sector. Furthermore, the implementation of electronic government can bring efficient and effective functions of Government, more transparent governance, and better citizen participation in the Government process [3]. Government Policy set out in Law of the Republic of Indonesia No. 14 of 2008 on Public Information Disclosure is information is information is information, statements, ideas, and signs containing values, meanings, and messages, both data, facts and explanations that can be viewed, heard and read presented in various packaging and formats in accordance with 
the development of information and communication technology electronically or nonelectronically.

One of the Government's policies is outlined in the form of presidential instruction No. 3 of 2003 on the development of electronic government, which the Government will encourage and realize information that is fast, precise, and accurate in the development of electronic government. The development was also supported by the instruction of the President of the Republic of Indonesia No. 3 of 2003, dated June 9, 2003 on the Policy and Strategy of National Development electronic government [4]. Internet-based electronic governance is making progress in public sector services. Basically electronic government application becomes a basic need for today's society, so that people easily get information that is quick, accurate and affordable. In the context of innovation Public sector services can change the quality of services in the public sector.

The innovation in question is the ability to deliver new value to customers. Innovation is more than just creating and launching new products. Innovation can be services, such as search engines or price comparison systems on the internet, ideas such as the earth orbiting the sun or humans evolving from apes, ideologies such as democracy, capitalism and communism. Socially including Public health, well-being, new types of sports, processes such as total quality management or new teaching methods, as well as business strategies such as launching a company or joining another [5]. Innovation in public services has a characteristic nature, namely its intangible nature because service and organizational innovation is not solely based on products that cannot be seen but rather on changes in the relationship of the perpetrator, namely between service providers and service receivers (service receivers, users), or relationships between various parts within the organization or partners of an organization [6].

The creation of an Innovation is one form in developing public services. This innovation is designed to bring out new ideas and creativity in a quality and high-quality design or program. With new ideas, the Government is better able to improve the quality of health services in the form of innovations for the progress of its own region.

The government has made regulation of the Health Law in the form of The Law of the Republic of Indonesia No. 36 of 2009 on Health mentions that every activity in an effort to maintain and improve the highest degree of public health is implemented based on nondiscriminative, definitive, and sustainable principles in order to establish Indonesia's human resources, as well as improving the health and competitiveness of the nation for national development.

The realization of an advanced development, a realm that is inseparable from the influence of globalization. Health Service is a place or facility in an effort to organize an activity in the Health program [7], [8]. The health service today is inseparable from the influence of the era of globalization. Globalization that leads to technological change has changed the way people live and globalization makes many organizations included in the Health Service program to innovate in providing better and quality services. One example is one of the Health Center in Gowa Regency of South Sulawesi that has implemented health services based on electronic government, namely Bontomarannu Sub-District. The program is known as Sikeroki which is classified as a form of innovation.

Sikeroki program at Bontomarannu Health Center that successfully gave gubrakan or breakthrough is the first in Gowa Regency that is able to display services in the form of internet from 25 health centers in Gowa Regency. Sikeroki program which is classified as a form of Innovation was born because it sees the situation and conditions in the field in the service that needs innovation, as well as realized health services based on electronic government. Based on the data, Bontomarannu is one of the districts in Gowa Regency that 
managed to provide the latest breakthrough with the health service in sikeroki innovation program. After two other programs, GS8 and Tali Ke Sorga, which have been brought to other sub-districts. So that in the hope that sikeroki program can be followed by 25 health centers in Gowa Regency.

Before the sikeroki program, health services became an issue, especially in the queue. Because queues are the biggest problem and very felt by Bontomarannu Health Center. However, Health Center Bontomarannu creatively made sikeroki's name into a Health information system and Integrated Health program. This program is an internet-based information service. This application system is very helpful service in Health Center, as well as the benefits of this system for the community that is no longer necessary to come to Health Center in taking the queue. Based on the above description, researchers are interested in analyzing the implementation and implementation constraints of Electronic Government in Health Service Innovation based on Sikeroki Program in Bontomarannu Health Center of gowa regency.

\section{Research Method}

The context of sikeroki's health service program is essentially based on primary and secondary data. Thus an important aspect of the methodology is the form of descriptive qualitative methods. By providing a clear and systematic picture related to the objects studied in order to provide valid information and data related to the facts and phenomena that exist in Bontomarannu Health Center.

\section{Result and Discussion}

In general electronic government is defined as electronic government which can indirectly involve the Government, institutions and society [9]. With electronic government access in public services can be categorized as a means of information that can make the service space open more widely [10]. One of the Government's policies in government electronics is outlined in the form of presidential instruction No. 3 of 2003 on the development of electronic government, which the Government will encourage and realize information that is fast, precise, and accurate in the development of electronic government. The development was supported by the instruction of the President of the Republic of Indonesia No. 3 of 2003, dated June 9, 2003 on the National Policy and Strategy of Electronic Government Development [4].

Government instructions on electronic government development began to be implemented at various levels of Government. As well as public services in Gowa Regency, one of them is Bontomarannu Health Center in its service innovation using internet-based information system with its program called sikeroki or health information system and integrated health program. The realization of the application of electronic government to Bontomarannu Health Center researchers want to know the legal umbrella in the establishment of sikeroki program in Gowa Regency. The response of stakeholders from the Kasubag Government of the Health Office on the Law in the innovation of sikeroki program in Health Center Bontomarannu i.e. the law or legal umbrella regarding this sikeroki program does not exist, but rather the program is a separate initiative of Health Center. With the direction of the Local Government at every head of the agency is able to make innovations in the form of electronic government.

Based on the results of interviews from the above informants can refer to the Government's policy in implementing electronic government in the field by having quality 
standards in the advanced program. As well as the implementation of the service can be seen from several main aspects.

Based on the type of service in electronic government can be divided into three main points [11], namely:

\section{Publish}

Publish in this class is a one-way communication, in which the Government publishes various data and information that it has to be directly and freely accessed by the public and other interested parties through the internet. Speaking of publishing on this sikeroki program the Government displays or publishes service information in the form of a website that www.puskesmasbontomarannukabgowa.com.

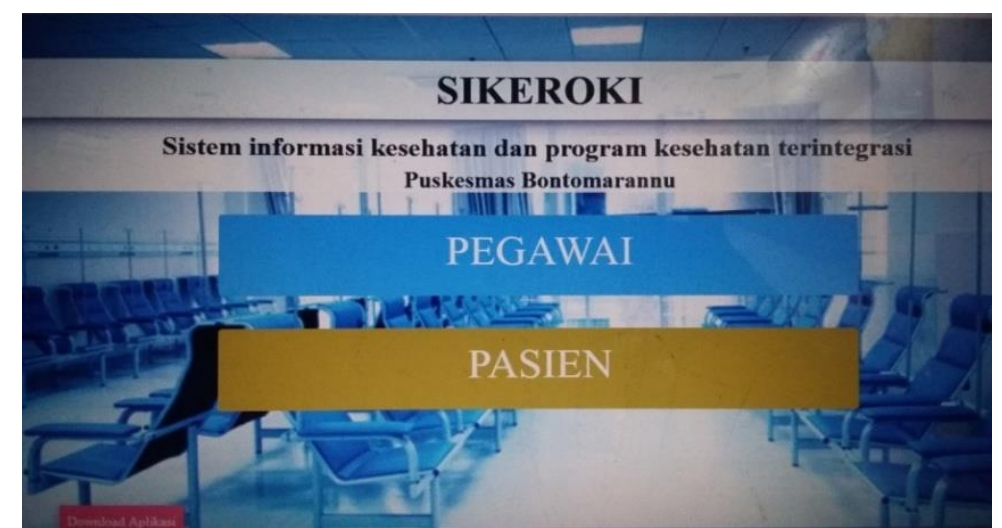

Figure 1. Sikeroki website homepage view

Source: www.puskesmasbontomarannukabgowa.com

Based on the display of service information in the form of the web above, here is the response of stakeholders from the Government Health Center Bontomarannu who need an information in implementing the program to the community:

"How to introduce this sikeroki system initially we make a brochure by displaying the website as well as the steps in entering the program. In addition, if there is a meeting meeting in the camat office or village that is where we introduce or socialize. And also delivered directly to the people who come to treatment by giving the website address, so no longer need to take the queue number simply by registering at home using android phone, just come to Health Center if the queue number is close".

Based on the results of the interview above, it shows that the application in introducing this sikeroki program is very important to achieve maximum service. In this case, Health Center are better able to maximize performance so that the principles in the service are more causal. Socialization in implementing a new program is very important. Where today's era of dissemination of information on social media is more in-step weighed the spread of manual forms. By looking at the conditions in this day and age where technology becomes a user of intelligent communication tools so that technology becomes a vital need with the internet kouta among today's society. The application of electronic government in Health Center in the form of the dissemination of brochures but information manual form. Although the dissemination of information is only limited through brochures but can take place information that is useful to the community. 


\section{Interact}

There has been a two-way communication between the Government and those concerned. There are two types of applications that can be used. The first is a form of portal where the related site provides searching facilities for those who want to search for data or information on a specific (in the publish class, users can only follow links only). The second is that the Government encodes channels where people can have discussions with interested units, either directly (such as chating, tele-conference, web-TV, etc.) or indirectly (via email, frequent ask questions, newsletters, mailing lists, etc.).

Based on the results of the research, the following are the results of interviews by it staff sikeroki application program:

"The problem of interaction is that there is a chating robot where the public can consult the problem of the disease how to solve it. So in this program more help the community in interacting and services because even though midnight want to consult can directly chat through this application".

The interaction process in this case can involve the Government, the community, as well as Health Center staff in this application through robot chating. In other words, the interaction of chating robots in internet-based service processes is a form of government in shaping better facilities and infrastructure than ever before. This internet-based application service is welcomed by the public with interaction services through chating robots that will not limit Health Center services for the community even if there are complaints of disease at night.

\section{Transact}

In this class, there is a two-way interaction such as in the interact class, only a transaction related to the transfer of money from one party to the other (not free, the public must pay for services provided by the Government or its partners). The transaction process in online media is a service provided by the Government. So that employees in the administrative field do not complicate it anymore in manual form. Similarly, people whose use is only transacting through online media only. In this case there are the results of interviews of public figures about transactions in the application of sikeroki program.

Here are the results of interviews of public figures as research informants in the application of sikeroki program:

"The payment in this sikeroki program does not exist. Maybe it is if the direct service in Health Center that do not have a complete card, such as bpjs is registered in another Health Center or hospital".

The results of the interview above reveal that the transactions in this application program do not exist at all. It's just a service process in this application program. So is the response of the community in the transaction process manually at Health Center. Transaction of sikeroki application or transaction manually, it is concluded that the service in the transaction of Health Center Bontomarannu in sikeroki program or direct service from Health Center does not exist. In addition to payments that are outside of Bontoamarannu sub-district or askes and BPJS that are not registered in Health Center pay but with the procedure tententu from the Health Center itself. 
Constraints of Electronic Government Implementation in Health Service Innovation based on Sikeroki Program in Bontomarannu Health Center Gowa Regency

The application of electronic government in Sikeroki Program-Based Health Service Innovation in Bontomarannu Health Center gowa regency certainly has obstacles or constraints in the running of a program. The inhibition of a program can be seen from the results of the research conducted. The constraints in the application of electronic government in health service innovation based sikeroki program in Bontomarannu Health Center gowa regency as follows:

\section{Internet Network Is Not Smooth}

Network systems in the general public are accustomed to complaints as a result of services or applications being opened must have an effect in entering the application or opening it must be slow. That's the information system in Bontomarannu Health Center based on internet applications. The downside of sikeroki application system is that the network is not smooth, besides that the service is also interrupted with the network system. So the community takes quite a long time in using this application. Inadequate network processes resulted in poor communication.

\section{Limitations of The Use of Communication Technology By The Public}

The use of communication technology by the public resulted in an obstacle in implementing the sikeroki program. Where bontomarannu community is seen from the level of education only until high school tingat education as well as dominant community work as need /farmer. So in technology only the public understands only information system technology that uses Mobile Android. The limited use of communication technology among the general public is a constrained internet-based program. In this case the need to increase human resources regarding the benefits of IT.

\section{People Are Not Familiar With Online-Based Service Systems}

People in online service systems find it complicated not to understand the internet system by getting used to just receiving calls and opening sms. The understanding of the community in terms of technology can still be said to be lacking because of the service process that can not be conditioned due to the network that is still inadequate so that the community uses more services manually in Health Center.

\section{Conclusions}

The application of electronic government in health service innovation based on sikeroki program in Bontomarannu Health Center gowa regency is a program that can help the community, especially in the queue. So people only access via mobile phone do not have to come in line manually. As well as the application of services in electronic government include 3 types namely (a) Publish, publish sikeroki program through the website www.puskesmasbontomarannukabgowa.com (b) Interact, in terms of interacting this sikeroki program involving robot chating, (c) Transact, for transact services in sikeroki program does not yet exist. The problem of the application of electronic government in health service innovation based on sikeroki program in Bontomarannu Health Center gowa regency there are some obstacles in the field namely, internet network that is not smooth can hinder the running of a program. Limited use of communication technology by the public due to lack of reliable 
human resources in telecommunications infrastructure. And the public is not familiar with online-based service systems is that ordinary people prefer manual processes.

\section{References}

[1] S. Supardal, "Penerapan ICT dalam Pelayanan Publik di Kabupaten Bantul," Otoritas J. Ilmu Pemerintah., vol. 6, no. 2, p. 120, Oct. 2016.

[2] Z. Mustapa, "Reformasi Birokrasi Melalui E-Governance : Peluang atau Tantangan Dalam Pelayanan Publik ?," Otoritas J. Ilmu Pemerintah., vol. 1, no. 2, Oct. 2011.

[3] R. Hardi and S. Gohwong, "E-Government Based Urban Governance on the Smart City Program in Makassar, Indonesia," J. Contemp. Gov. Public Policy, vol. 1, no. 1, 2020.

[4] D. Witarsyah, T. Sjafrizal, M. F. MD Fudzee, and M. A. Salamat, "The Critical Factors Affecting e-Government Adoption in Indonesia: A Conceptual Framework," Int. J. Adv. Sci. Eng. Inf. Technol., vol. 7, no. 1, p. 160, Feb. 2017.

[5] L. Carter and F. Bélanger, "The utilization of e-government services: Citizen trust, innovation and acceptance factors," Inf. Syst. J., 2005.

[6] I. Mergel, "Agile innovation management in government: A research agenda," Gov. Inf. Q., vol. 33, no. 3, pp. 516-523, Jul. 2016.

[7] M. M. Tahir and A. Harakan, "Inovasi Program Kesehatan 24 Jam Dalam Mewujudkan Good Health Care Governance di Kabupaten Bantaeng," J. MUQODDIMAH J. Ilmu Sos. Polit. dan Hummaniora, 2017.

[8] N. Khaerah, A. Harakan, and J. Junaedi, "Call Centre Brigade Siaga Bencana Sebagai Strategi Pelayanan Kesehatan di Kabupaten Bantaeng," JDP (JURNAL Din. PEMERINTAHAN), vol. 2, no. 1, pp. 51-64, Apr. 2019.

[9] M. Yildiz, "E-government research: Reviewing the literature, limitations, and ways forward," Gov. Inf. Q., 2007.

[10] H. Wang and B. L. Rubin, "Embedding e-finance in e-government: a new egovernment framework," Electron. Gov. an Int. J., vol. 1, no. 4, p. 362, 2004.

[11] R. E. Indrajit, Electronic government: strategi pembangunan dan pengembangan sistem pelayanan publik berbasis teknologi digital. Yogyakarta: Penerbit Andi, 2002. 